\author{
О. В. Коваль ${ }^{1}$, В. О. Кузьміних ${ }^{2}$ \\ ${ }^{1}$ Інститут проблем реєстрації інформації НАН України \\ вул. М. Шпака, 2, 03113 Київ, Україна \\ e-mail: avkovalgm@gmail.com \\ ${ }^{2}$ Національний технічний університет України «КПІ» \\ Проспект Перемоги, 37, 03056 Київ, Україна
}

\title{
Реалізація сценарного підходу в управлінні проектами на основі типових задач
}

\begin{abstract}
Розглянуто питання зв'язку між функиіональними задачами підрозділів і задачами план-графіків проектів. Запропоновано використання сиенаріїв виконання проектів на основі типових задач, щуо визначаються функціональними обов'язками підрозділів для підприємств з функціональною організаційною структурою. Запропоновано створення репозиторію сценаріїв і репозиторію типових задач. Представлено схему обробки даних для аналізу стану виконання проектів. Запропоновано структуру програмного забезпечення управління проектами за сценаріями з використанням типових задач.
\end{abstract}

Ключові слова: корпоративна система управління проектами, сценарії проектів, типові задачі, репозиторій задач, репозиторій сиенаріїв, реєстр проектів.

\section{Вступ}

Підприємства 3 функціональною організаційною структурою (functional organization structure) [1], діяльність яких спрямована на виконання повсякденних функцій, що визначаються їхнім функціональним призначенням, є однією $з$ найбільш розповсюджених типів підприємств операційного типу, тобто підприємств, основна діяльність яких може бути описана певними бізнес-процесами. Для таких підприємств проекти, як правило, є джерелом якісних і кількісних змін у виконанні бізнес-процесів підприємства. Ведення проектів для таких підприємств не $є$ основним видом діяльності, але складає значну частину загального обсягу інвестиційної діяльності та є основою конкурентних змін у підприємстві.

У підприємствах і установах з функціональною організаційною структурою, що характеризується ієрархічною підпорядкованістю та документально закріпленими функціями співробітників і підрозділів, для досягнення цілей стратегічного управління найбільш перспективним механізмом $\epsilon$ управління портфелем проектів

(C) О. В. Коваль, В. О. Кузьміних 
підприємства $[1,5]$. Це вимагає побудови на підприємстві загальної корпоративної системи управління проектами (КСУП) для усього підприємства [8].

Застосування проектного підходу на підприємствах з функціональною організаційною структурою має декілька принципових ознак, що відображають особливості управління проектами в них. Ці ознаки є основою для використання сценаріїв при виконанні проектів.

По-перше, наявність аналогічних, повторюваних за послідовністю і складом задач, процедур підготовки та виконання проектів у рамках окремих напрямків діяльності (IT, маркетингу, продажів, виробництва виробів і т.д.), але різних для різних напрямків діяльності. Тобто процеси, що описують основні етапи реалізації цих проектів аналогічні, а набори виконуваних завдань повторювані, що дозволяє побудувати відповідні сценарії та шаблони задач і зберігати їх для багаторазового використання.

По-друге, наявність типових проектних задач для різних підрозділів підприємства, які вирішуються в підрозділах у рамках їхніх функціональних обов'язків, що визначені положеннями про діяльність цих підрозділів [4, 8]. Таким чином, будь-яка задача в проекті може бути однозначно віднесена до однієї зі стандартних (типових) задач одного із підрозділів. Ніякі інші задачі, крім визначених функціями підрозділів і функціональними обов'язками їхніх співробітників не можуть виконуватися. Тобто будь-яка задача будь-якого проекту завжди відповідає певній функціональній задачі підрозділу, що дає можливість отримувати усереднену оцінку термінів їхнього виконання і накопичувати інформацію про терміни виконання таких завдань для подальшого використання при побудові планів проектів.

По-третє, існує необхідність оперативного аналізу стану як окремих проектів, так і агрегованих груп проектів (портфелів, програм, папок тощо). Рівні агрегації проектів визначаються як структурою підприємства, так і фінансово-бюджетними, географічними та іншими властивостями проектів і особливостями підприємства, що має бути враховано при побудові КСУП відповідно до напрямків роботи підрозділів підприємства

При цьому під сценарієм розуміється можливий набір подій, що визначає розвиток тих чи інших факторів, які впливають на результат діяльності, тобто сценарій визначає логічно обумовлену послідовність задач проекту, що мають бути виконані для досягнення мети проекту [6]. При управлінні проектами характерно використання типових сценаріїв.

Головними проблемами побудови КСУП у таких підприємствах є необхідність [2]:

- урахування потреб виконання задач проектів 3 операційною діяльністю підприємств;

- орієнтації програмних засобів на повторюваність типових проектів і задач;

- аналізу груп проектів, що побудовані за певними ознаками (портфелів, програм, папок) [10];

- накопичення та збереження даних щодо часу виконання певних задач для певних типів проектів з метою оцінки для нових типових проектів [9];

- оперативного відображення ходу виконання проектів та агрегованих груп проектів у різних уявленнях (view) для різних груп користувачів з різними правами доступу до даних. 
На сьогодні окремі з цих проблем лише частково вирішені у різних програмних системах (таких як Primavera Project Planner, Spider Project, Turbo Planner (paніше Turbo Project), Advanta PMS та інших), але сукупність цих проблем не вирішена повною мірою у жодній з них.

Метою статті є: запропонувати підхід реалізації програмної системи, що дає можливість організовувати процеси управління проектами на підприємствах 3 функціональною організаційною структурою за певними сценаріями, які побудовані на базі функціональних задач підрозділів з подальшим відображенням результатів у реєстрі проектів як засобів загального моніторингу проектів підприємства. Це дає можливість визначати резерви покращення самого процесу управління проектами шляхом оптимізації план-графіків виконання на основі оцінки можливостей завантаження виконавців функціональних підрозділів і надати більш повну інформацію для керівництва про стан виконання проектів.

Структура елементів КСУП, що побудована на основі використання сценаріїв вирішення типових задач, показана на рис.1. Вона містить такі основні елементи:

- репозіторій сценаріїв проектів (Project Scenario Repository) - сховище базових типових сценаріїв вирішення задач управління проектами (workflow);

- репозіторій типових задач управління проектами (Standard Task Repository) - сховище базових типових завдань проектів, відповідних функцій підрозділів, що їх виконують;

— MS Project Management 2010/2013 - управління і супровід окремих проектів із використанням шаблонів проектів і супровід етапів планування, виконання, завершення проекту;

- реєстр проектів (Project Registry) - реєстр проектів, що виконуються та архів уже виконаних із засобами аналізу і моніторингу.

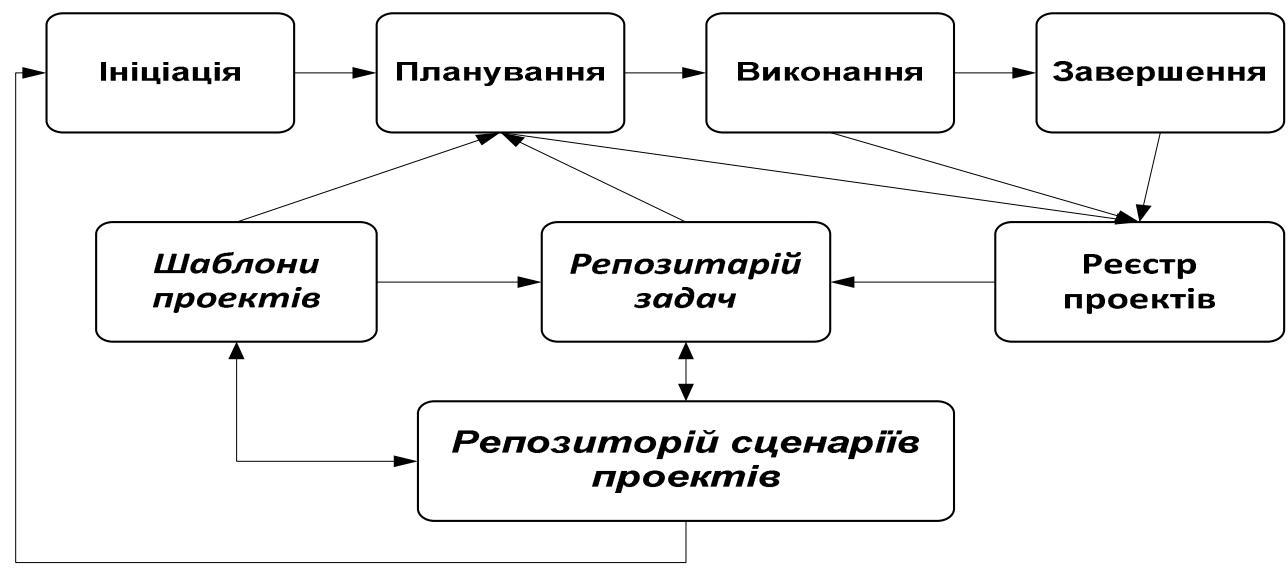

Рис. 1. Базові елементи при використанні сценаріїв 3 типовими задачами

\section{Репозиторій сценаріїв вирішення виконання проектів (Project Scenario Repository)}

Повторювані для підприємств 3 функціональною організаційною структурою процеси управління проектами можуть розміщуватися, накопичуватися та збері- 
гатися для подальшого використання в ПЗ Project Scenario Repository (наприклад 3 використанням засобів MS Share Point, Nintex чи інших) як сховищі описів бізнеспроцесів (workflow), характерних для конкретного підприємстві.

Широко поширені програмні засоби ведення проектів, таких як MS Project, Primavera Project Planner та інші, розраховані тільки на підтримку етапу виконання проекту. Такі етапи як ініціалізація проекту, оцінка доцільності виконання запропонованого проекту, розбивка проекту на етапи і роботи, деталізація робіт і т.п. залишаються за рамками функцій цих систем. У разі застосування проектного управління в організаціях з функціональною структурою необхідний більш загальний і цілісний підхід, в якому проектна діяльність розглядається поряд з операційною діяльністю як її невід'ємна частина.

Частково, у застосуванні до області інформаційних технологій ці питання вирішені в MOF (Microsoft Operations Framework) [3, 6], де проект включається в життєвий цикл продукту, проте в цьому випадку розгляд стосується тільки специфіки IT-проектів, спрямованих на створення IT-сервісів і продуктів, а сама процедура планування і виконання проектів не описана.

Відповідно до MOF можна побудувати наступну структуру типових сценаріїв проектної діяльності на підприємствах з функціональною структурою.

1. Ініціація (Initiation) - перевірка відповідності бізнес-вимогам та їхнє узгодження, оцінка надійності рішення, виявлення джерел та умов фінансування, формування групи управління проектом та паспорту проекту.

2. Планування (Planning) — попереднє планування (верхній рівень та бачення планів окремих частин проекту), планування проекту в цілому (проблеми, ризики, підрядники), затвердження плану проекту та виконавців.

3. Виконання (Execution) - створення продукту/послуги, стабілізація рішення (за результатами тестування та дослідної експлуатації), розгортання продукту/послуги (документи щодо розгортання та експлуатації).

4. Завершення(Closing) - підготовка та передача планів і документів до архіву, внесення даних до репозиторіїв.

5. Моніторинг і контроль управління проектами (Monitoring and Controlling — Project Management) для етапів 2-4:

- управління проектом, аналіз ризиків і відповідність їхнім бізнес-вимогам;

- зміни термінів виконання задач та їхнього складу (необхідні і плановані зміни та їхні наслідки);

— управління командою проекту (відповідальності та повноважень по ролях і задачах проекту).

Функціональні розділи сценаріїв виконання проектів можуть значно відрізнятися для різних за типом проектів, але для однотипних проектів вони будуть містити досить однорідні за складом компоненти. Типові сценарії виконання проектів визначаються як особливостями типів проектів, так і особливостями функціональних можливостей підрозділів підприємства

\section{Репозиторій типових задач ( Standard Task Repository)}

Репозиторій типових задач (Standard Task Repository) являє собою перелік стандартних типових проектних завдань, побудований на основі обмеженого пе- 
реліку відповідних функціональних завдань підрозділів. Він зберігає і накопичує інформацію про виконання проектних завдань у ПО Standard Task Repository. При цьому, під репозиторієм типових задач розуміється як сховище часових оцінок виконання функціональних задач за результатами їхнього виконання у проектах (середнього часу виконання, відхилень реального часу виконання у різних проектах від середнього значення, оцінки дисперсії та ін.) та програмні засоби їхньої обробки, так документи, що відносяться до певних задач проектів.

Хоча метою реалізації проектів, за визначенням, $є$ унікальний продукт $[1,8]$, але на практиці у більшості компаній реалізують однотипні, відповідно до напрямку діяльності, проекти. Такі проекти включають велику кількість типових задач. Особливими відзнаками типових задач проектів є наступні $[9,10]$ :

— перелік задач і їхня послідовність у проектах відомі та подібні;

— на підприємстві є досвід отримання результатів із застосуванням наборів типових задач;

- закономірна повторюваність задач від проекту до проекту;

- задачі виконуються у рамках функціональних обов'язків підрозділів і пов'язані з посадовими обов'язками співробітників підрозділів.

Репозиторій типових задач має подвійне призначення:

- збереження повторюваних задач для майбутнього використання при створенні планів нових проектів;

- використання часових даних з виконання задач в кожному проекті для проведення статистичної оцінки середнього часу виконання задач за всіма проектами і дисперсії часових даних, у тому припущенні, що розподіл часу є випадковим і близьким до нормальному розподілу.

Якщо стандартна задача повторюється часто і без значних змін (що є звичайним для проектів у функціональних організаціях), тоді середній час виконання задачі отриманий з попередніх проектів може використовуватися для визначення часу виконання задачі в новому проекті. Дисперсія, що отримується зі статистичної оцінки, може використовуватися для оцінки найбільшого відхилення в часі виконанні задачі (правило 3-х сігм) [9]. Ця величина може використовуватися для оцінки ризику запізнення виконання задачі. Окрім того, використання тривалості задачі, меншої ніж середній час виконання стандартної задачі, призведе до значного зростання ризику несвоєчасного завершення задачі. Відносно велике значення дисперсії може служити індикатором нестабільності у виконанні задачі. Тому такі задачі варто розміщати поза критичним шляхом проекту, щоб вони не впливали на час виконання всього проекту в цілому, або, принаймні, треба приймати міри на зменшення впливу таких задач на весь проект.

Репозиторій стандартних задач $є$ сукупністю динамічних структур даних у базі даних, в якій зберігаються всі стандартні задачі зі своїми часовими та додатковими параметрами, та програмного забезпечення, яке надає такі сервіси як:

- додавання нової задачі до репозиторію;

— вибір задач з відповідними параметрами для використання при плануванні;

- статистична оцінка виконання задач, що оновлює визначені параметри задачі по завершенні іiї в поточному проекті та ін.

Багато проектів можуть бути згруповані відповідно до однакових наборів стандартних задач, що використовуються в них, та відносно потоків робіт, що ви- 
користовуються при управлінні життєвими циклами проектів. Така класифікація може використовуватися для побудови шаблонів для кожного типу проектів, що зведе процедуру планування нового проекту до редагування дат початку стандартних задач і додавання унікальних задач за потребою.

Більш того, кожна стандартна задача може бути об'єднана 3 набором шаблонів документів, які мають генеруватися в процесі її виконання, таким чином зменшуючи час, необхідний для планування проекту і супроводження виконання проекту. Такі необов'язкові набори шаблонів документів зберігаються в репозиторії стандартних задач разом із самими стандартними задачами.

При такому підході будь-які задачі проектів, що включають до план-графіків, $\epsilon$ взаємно однозначним відображенням відповідних функціональних задач певних підрозділів підприємства. Тому, формально, виконання робіт підрозділів у рамках бізнес-процесу, що є основними для підрозділів, не вступає у протиріччя з виконанням проектних робіт. Крім того, це дає можливість звести необмежену кількість видів проектних задач до строго обмеженого переліку типових функціональних задач підрозділів, на базі яких будується репозиторій типових проектних задач.

Обмежена кількість типових задач у репозиторії, у свою чергу, дає можливість накопичувати якісну інформацію щодо виконання типових задач проекту підрозділами, і на цій інформації будувати ймовірнісні часові оцінки виконання проектів узагалі на етапі попередньої підготовки план-графіків проектів.

Життєвий цикл перерахунку та уточнення часових параметрів задач показано на рис. 2. Цикл починається з етапу планування. На цьому етапі, при плануванні нового проекту, менеджер бере стандартні задачі та їхні параметри часу безпосередньо з репозитарію задач і поміщає їх у план проекту, визначає їхні дати початку і посилання на інші задачі відповідно до реалій проекту. При виконанні керівник проекту вносить корективи в дати початку та тривалості завдання, якщо це необхідно. Після того як задача закінчена, з'являться нові дані про час виконання.

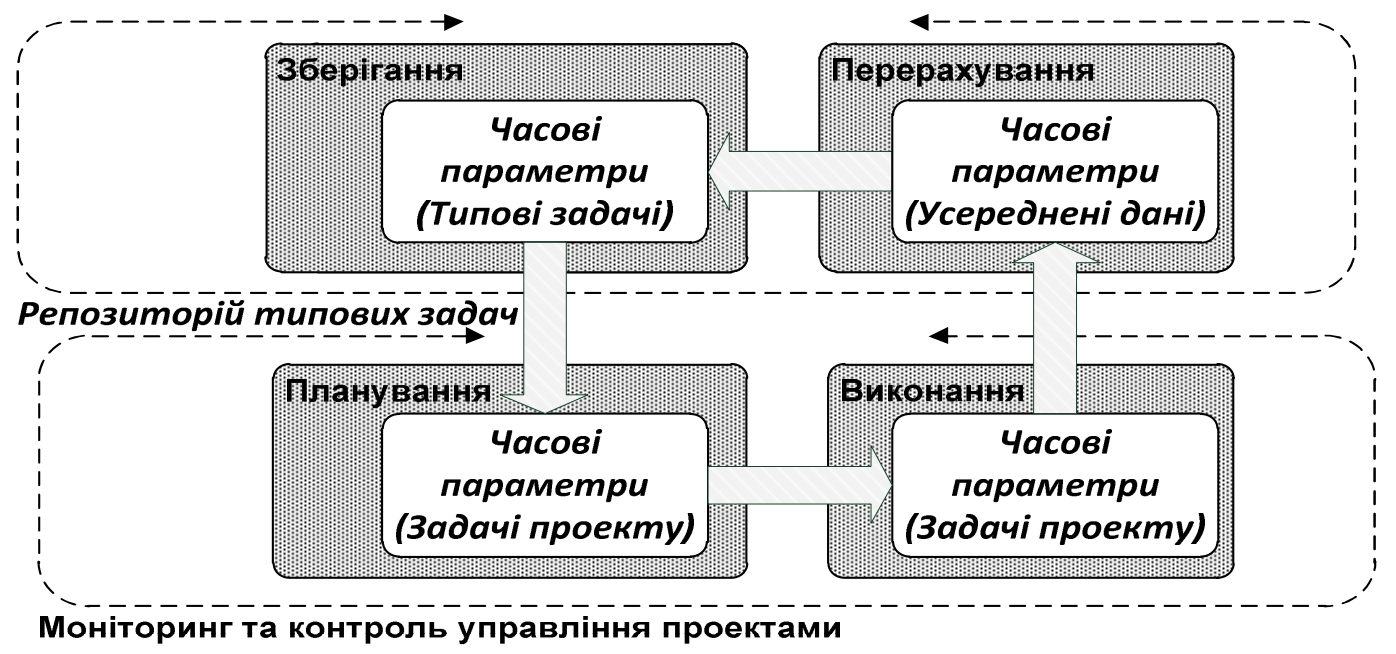

Рис. 2. Життєвий цикл перерахунку та уточнення часових параметрів задач 
На основі попередніх даних час для стандартних задач і нові фактичні дані про час від поточного проекту обчислюються нове значення середнього часу виконання і дисперсії в припущеннях, що значення розподілені нормально. Такі припущення можуть бути зроблені для підприємств де добре визначаються і регулюються процеси виконання, що характерно для підприємств з ієрархічною функціональною структурою.

\section{Проблеми контролю і управління}

На сьогодні у більшості випадків управління проектами на підприємствах і в організаціях у державній та комерційній сфері знайшло своє застосування програмне забезпечення (П3) MS Project 2010 та MS Project 2013, як унаслідок своєї помірної вартості, так і достатньої для більшості задач функціональності. Подальший розвиток цих продуктів у напрямку хмарних технологій робить їх ще більш привабливими для реалізації. До суттєвих переваг MS Project 2010 та MS Project 2013 можна віднести:

- простоту впровадження та освоєння;

- наявність великої кількості підготовчих курсів для навчання;

- достатню кількість літератури щодо впровадження та використання;

- значну кількість кваліфікованих спеціалістів.

Проблеми використання ПЗ MS Project на сьогодні є похідними від первинної структури цього ПЗ як засобу управління окремими проектами.

Серед них, з точки зору аналізу портфелів та інших агрегованих груп проектів, найбільш важливими є наступні:

— відсутність можливості побудови агрегованих груп проектів за довільними ознаками;

— відсутність можливості рольового розподілу доступу за агрегованими групами проектів та окремими проектами;

— відсутність звітів за агрегованими групами проектів;

- відсутність можливості аналізу виконання бюджету проекту (портфелю проектів);

- відсутність можливості відстеження критичних дат виконання агрегованих груп проектів (портфелю чи папки проектів);

- відсутність можливості ефективного відстеження стану виконання агрегованих груп проектів (портфелю чи папки проектів).

Для усунення цих недоліків можуть бути використані можливості спеціалізованого програмного засобу «Реєстр проектів».

\section{Основні елементи системи управління проектами за сценаріями}

Управління проектами і портфелями проектів на підприємствах з великими обсягами операційної діяльності і функціональною організаційною структурою посідає важливе місце, як інструмент досягнення стратегічних цілей підприємства, інструмент реагування на швидкі зміни у оточуючому середовищі та інструмент оптимізації бізнес-процесів підприємства, що характеризують поточну операційну діяльність. 
Щоправда, поняття портфелю проектів, яке прийшло в управління проектами з інвестиційного менеджменту, ще не повністю встановилось, і в різних роботах носить дещо різне значення. В багатьох джерелах вважається, що існує єдиний поточний портфель проектів підприємства, що складається 3 проектів, які найбільш повно відповідають задачам досягнення стратегічних цілей підприємства. В більшості практичних випадків портфелі можуть розглядатись як засіб агрегації проектів на різних рівнях. Такий підхід особливо доцільний для проектної діяльності в державних підприємствах з функціональною організаційною структурою. При цьому проекти можна розглядати як головний механізм проведення будьяких змін, доповнень, інновацій у підприємствах, головний прибуток яких надходить від операційної діяльності, що зумовлено їхньою функціональною організаційною структурою з жорсткою вертикаллю управління. Портфелі проектів у цьому випадку тісно пов'язані з функціональною структурою підприємства. Проекти частіше всього виконуються в рамках одного підрозділу або напрямку. Тільки наскрізні проекти, в яких задіяні різні напрямки, різні філії і різні підрозділи, можуть бути віднесені до проектів портфелю всього підприємства.

При такому підході досить логічно визначається зона відповідальності кожного $з$ підрозділів, а керівниками відповідних проектів стають керівники відповідного рівня у відповідних напрямках. Як правило, необхідність у аналізі стану різних груп проектів за певними ознаками є невід'ємною частиною стратегічного управління підприємством. Аналіз стану проектів по агрегованим групам проектів дає можливість достатньо об'єктивно і точно дати відповідь про наявний стан виконання та загальні результати виконання інвестиційних програм і планів реалізацiï.

Агрегація може виконуватись як за структурно-ієрархічними ознаками (наприклад - підприємство/організація, департамент/філія, відділ/відділення і т.д.), так і за фінансовими, часовими, технічними, технологічними ознаками, за напрямками робіт чи приналежності до заходів та інше. Ознаки проектів можуть бути як обов'язковими ознаками проекту, які визначені на MS Project Server, так і такі, що визначаються потребою в агрегації проектів для групового чи порівняльного аналізу, тобто, аналізу сумарних, осереднених чи порівняних даних щодо виконання проектів. Крім того, агрегація може проводитися за декількома ознаками, тобто комбінаціями ознак (наприклад - результати роботи за проектами певного відділу за перший квартал поточного року). Така задача є досить складною та громіздкою за складом і розміром обсягів інформації, що має бути оброблена для її вирішення. Для вирішення таких задач використовується ПЗ «Реєстр проектів» (Project Registry), як надбудова на над Project Server, що взаємодіє з ним через PSI (Project Server Interface).

На рис. 3 показано структуру програмної реалізації, що описує основні модулі та їхню взаємодію у системі сценарного управління проектами .

На рівні Project Server формуються дані про проекти, їхніх керівників, стан виконання, дані щодо договорів з постачальниками та субпідрядниками за цими проектами та інша додаткова інформація.

Синхронізатори ПЗ «Реєстр проектів» забезпечують актуальність інформації та можливість їі оновлення. 


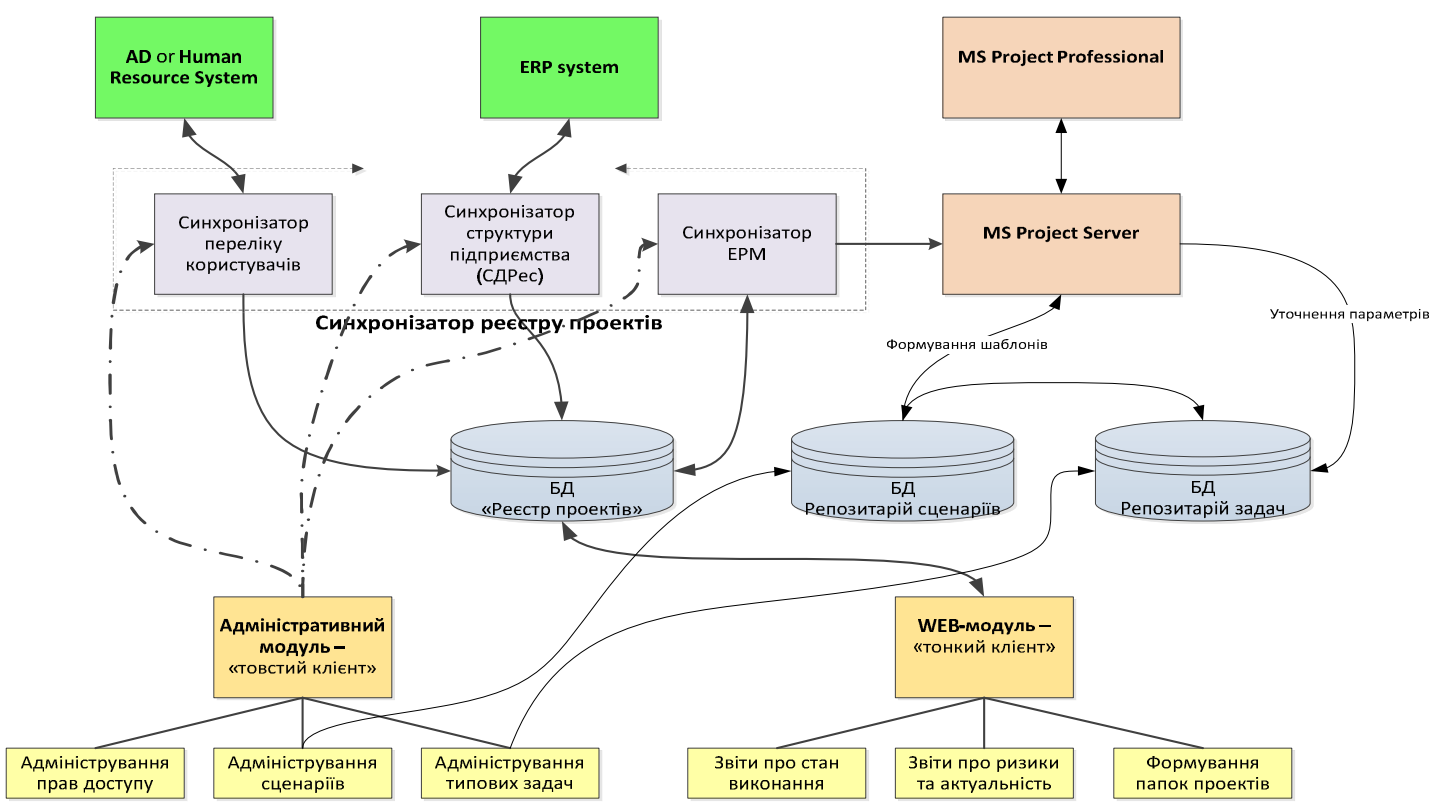

Рис. 3. Структура взаємодії елементів програмного засобу «Реєстр проектів»

БД «Репозитарій сценаріїв» та БД «Репозитарій задач» формуються відповідно до особливостей підприємства засобами Адміністративного модулю.

- веб-модуль призначений головним чином для відображення основних результатів виконання проектів та агрегованих груп проектів, дає можливість управління процесом аналізу стану як окремих проектів, так і портфелів та інших агрегованих груп проектів. Він дозволяе користувачеві, залежно від прав доступу, отримувати доступ до проектів і їхніх агрегованих груп, створювати та зберігати нові агреговані групи проектів для їхнього подальшого аналізу;

- веб-модуль використовується для обробки і візуалізації отриманих результатів аналізу виконання проектів та їхніх агрегованих груп і дозволяє отримувати різного роду звіти, як текстові, так і графічні, про поточний стан проектів і їхніх агрегованих груп, які супроводжуються та контролюються в рамках КСУП.

Основними функціями проекту ПЗ «Реєстр проектів» $є$ наступні.

1. Автоматичне створення реєстру проектів із використанням усієї сукупності проектів, опубліковані на сервері Project Server.

2. Формування структури людських ресурсів відповідно до організаційної структури підприємства та завантаження цих даних на Project Server.

3. Візуалізація стану проектів і їхніх агрегованих груп для певних груп керівників та аналітиків без доступу до MS Project.

4. Фільтрація проектів - дозволяє вибрати групу проектів (організувати папку проектів) за будь-якими ознаками проектів, що мають значення для проведення групового аналізу стану виконання проектів, опублікованих на Project Server.

5. Аналіз стану проектів - дає можливість оцінити стан виконання, ризиків та актуальність даних для кожного проекту. 
6. Звіти за проектами та агрегованими групами проектів мають бути створені за допомогою відповідних шаблонів, що пов'язані з типами проектів і сценаріями їхнього виконання.

7. Архівування проектів та агрегованих груп проектів дає можливість відновити інформацію про проект і порівняти зі станом даних за попередні періоди.

\section{Висновки}

У роботі розглянуто питання використання сценарії для виконання проектів на підприємствах з ієрархічною функціональною організаційною структурою, встановлення зв'язку між функціональними задачами підрозділів та задачами план-графіків проектів. Зв'язок між типовими функціональними задачами підрозділів і відповідними задачами проектів встановлюється за допомогою репозиторію типових задач, які є відображенням сукупності функціональних задач підрозділів на задачі проектів. Це дає можливість зменшення ризику невірної (недостатньо точної) оцінки термінів виконання задач проектів, з одного боку, та побудови сценаріїв виконання проектів різними підрозділами, з іншого. Для збереження та використання сценаріїв запропоновано використання окремого репозитарію сценаріїв, що відповідають різним типам проектів підприємств.

Представлено структуру взаємодії програмних модулів, що реалізують запропонований підхід. Розроблюваний програмний продукт будується на використанні MS Project 2010/2013 як базової системи ведення план-графіків проектів, програмних засобів управління репозиторіями, що взаємодіє з базою даних MS Project Server через програмний PSI-інтерфейс, та веб-засоби для користувачів.

Описаний у статті підхід став основою для реалізації програмного засобу «Центр звітів - реєстр проектів», що був реалізований і пройшов апробацію протягом двох років у ПАТ «Укртелеком». Використання такого підходу дало можливість значно зменшити кількість необхідних ліцензій MS Project для надання необхідної для керівництва звітної інформації про хід виконання проектної діяльності.

Наведена структура системи управління проектами з використанням сценаріїв для підприємств і установ з функціональною організаційною структурою дозволяє розробити комплекс програмних засобів, що забезпечує достатньо повне i цілісне керування проектами і агрегованими групами проектів, а також дає можливість ліквідувати основні протиріччя управління між проектною та операційною видами діяльності на підприємстві.

1. Guide to the Project Management Body of Knowledge Project Management Institute, Inc. USA.: PMI. — 2008. — 437 p. — ISBN 978-1933890-51-7.

2. Богданов В. Управление проектами. Корпоративная система - шаг за шагом / В. Богданов. - Изд-во «Манн, Иванов и Фербер, Эксмо», 2012. — 248 с.

3. Dave Pultorak. MOF - Microsoft Operations Framework: V4.0 / Pultorak Dave. — 2008. 180 p. - ISBN 9087532865. 
4. Джеральд И. Кендалл. Современные методы управления портфелями проектов и офис управления проектами. Максимизация ROI / Джеральд И. Кендалл, Стивен К. Роллинз. - M.: 3АO «ПМОФТ», 2004. - 569 с.

5. Друкер П. Эффективное управление предприятием / П. Друкер. - М.: Изд. дом «Вильямс», 2008. - $224 \mathrm{c}$.

6. Коваль О.В. Верифікація комп'ютерної моделі системи інформаційного управління / О.В. Коваль, К.А. Зайцева // Вісник НТУУ «КПІ» Інформатика, управління та обчислювальна техніка. - 2014. - № 61. - C. 43-48.

7. Eric S. Norman. Work Breakdown Structure / Eric S. Norman. - 2008. - 304 c. — ISBN 9780470177129.

8. Кузьміних B.A. Трирівнева корпоративна система управління проектами / В.А. Кузьміних // Реєстрація, зберігання і оброб. даних. - 2009. — Т. 11, № 3. - С. 75-82.

9. Кузьміних В.A. Оцінка часу виконання типових задач проектів на підприємствах з функціональною організаційною структурою / В.А. Кузьміних, О.В. Коваль, М.П. Воронько // Реєстрація, зберігання і оброб. даних. - 2012. - Т. 14, № 3. - С. 70-82.

10. Управління агрегованими групами проектів / Кузьміних В.А., Коваль О.В., Хаустов Д.В., Коростельова С.Ю. // Реєстрація, зберігання і оброб. даних. - 2011. - Т. 13, № 3. - С. 106-116.

Надійшла до редакції 03.03.2015 